American Journal of Environmental Sciences 3 (4): 259-264, 2007

ISSN 1553-345X

(C) 2007 Science Publications

\title{
Methods of Utilizing Tropical Peat Land for Housing Scheme
}

\author{
${ }^{1}$ Youventharan Duraisamy, ${ }^{2}$ Bujang B.K. Huat and ${ }^{2}$ Azlan A. Aziz \\ ${ }^{1}$ University Malaysia Pahang, Malaysia \\ ${ }^{2}$ University Putra Malaysia, Serdang, Selangor, Malaysia
}

\begin{abstract}
This paper discusses some of the methods and recent technologies in utilizing cheap marginal land such as tropical peat for housing scheme. Buildings on peat are usually suspended on piles, but ground around it may still settle. Therefore a suitable method of construction should be tackle to overcome serious problem such as localized sinking and slip failure, massive primary and long term (creep) settlement. With the ever increase in the cost of living and the decrease in suitable land for construction, avoidance of marginal tropical peat soil is never going to be the popular choice among the developers and town planners. This paper gives some insights on the construction methods that could be possibly employed to develop marginal ground such as tropical peat soil.
\end{abstract}

Keywords: Cement column, deep soil mixing, EPS foundation system, excavation and replacement, organic soil, prefabricated vertical drain, peat soil.

\section{INTRODUCTION}

Cheap marginal land for housing includes soft ground like peaty soils. Peat is found in many countries throughout the world. In the US, peat is found in 42 states, with a total acreage of 30 million hectares. Canada and Russia are the two countries with a large area of peat, 170 and 150 million hectares respectively. The total area of tropical peat swamp forests or tropical peat lands in the world amounts to about 30 million hectares, two thirds of which are in Southeast Asia. In Malaysia, some 3 million hectares (about 8\%) of the country land area is covered with peat (Fig. 1). In Indonesia peat covers about 26 million hectare of the country land area, with almost half of the peat land total is found in Indonesia's Kalimantan. Peat is also found in many other part of Asia like Japan, Bangladesh, and China.

Peat commonly occurs as extremely soft, wet, unconsolidated superficial deposits normally as an integral of wetland systems. They may also occur as strata beneath other superficial deposits. The term peat is described as a naturally occurring highly organic substance derived primarily from plant materials. It is formed when organic (usually plant) matter accumulates more quickly than it humidifies (decays). This is usually occurs when organic matter is preserved below high water table like in swamps or wetlands. Peat is therefore superficial deposits or soils with high organic matter content. However, the cut-off value of the percentage of organic matter necessary to classify a superficial deposit or soil as peat varies throughout the world, usually depending on the purpose of classification. This cut-off value also serves to differentiate peat from superficial deposits or soils with lesser amounts of organic content. The terms peat and organic soils, used for describing soils with an organic content, were once synonymous but term organics soils is presently used for superficial deposits or soils that contain organic matter.

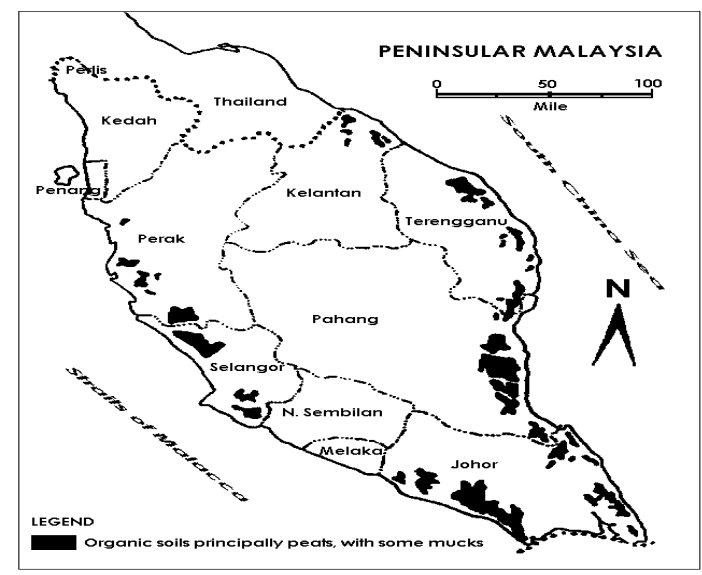

Fig. 1: Distribution of peat land in Peninsular Malaysia ${ }^{[1]}$

When a soil is subjected to an increase in compressive stress due to foundation load the resulting soil compression (generally called settlement) generally consists of elastic compression (immediate settlement),

Corresponding Author: Bujang B.K. Huat, Faculty of Engineering, University Putra Malaysia, 43000 Serdang Selangor. Tel: 603-89466368, Fax: 603-86567129 
primary compression (consolidation settlement) and

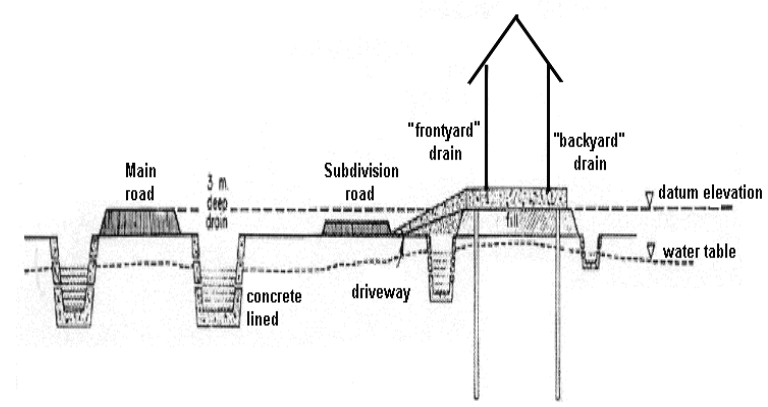

(a)

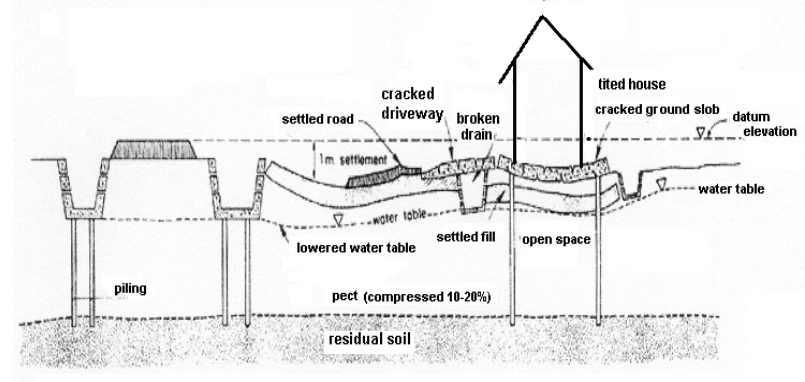

(b)

Fig. 2: (a) Typical section through a housing estate (immediately after completion of construction)

(b) Several years after completion of construction ${ }^{[1]}$.

secondary compression. Compared with mineral soils, peat soils are highly organic and highly compressible. Its compression or settlement process may take a considerably longer amount of time. Peat generally has low undrained shear strength and high compressibility. Buildings on peat are usually suspended on piles, but the ground around it may still settle, creating a scenario as depicted in Fig. 2.

Case History: One of the towns in Malaysia that is badly affected by land subsidence on peat is Sibu Town in Sarawak (Fig. 3). The problem is mainly caused by either uncontrolled land filling or ground water lowering due to over-drainage (or both). A substantial part of the town centre is currently in a state of disrepair with rows of residential housing units being abandoned altogether, due to excessive ground subsidence. Ground subsidence has also resulted in negative gradients to drainage, resulting in unhealthy water stagnation in many parts of the town. Much of the town is also prone to flooding, both locally as well as regionally. The regular occurrence of flooding is however the very basis on which the peat soils are geologically formed and sustained.

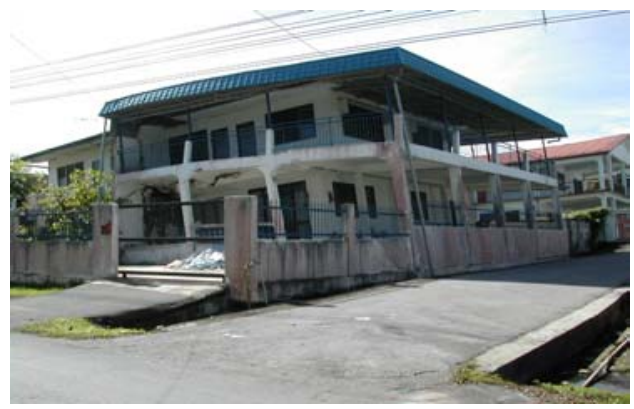

(a)

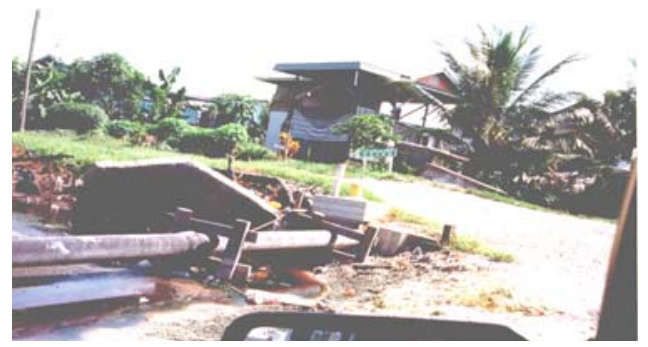

(b)

Fig. 3: (a) Ground subsidence of Sibu Town (b) Damage to infrastructure ${ }^{[2]}$

Line structures, such as the road embankment which are subjected to not only to instability such as localized sinking and slip failure but also to a tremendous massive primary and long term settlement. Looking at the scenarios such as in Sibu Town, engineers seek to avoid building on this problematic ground. Avoidance is sometimes possible by changing the location of the construction. However this is not always possible. In cases where there is no where else to avoid such as those that often occurs in the coastal lowland due to high pressure for land for development, even these less desirable land have to be developed.

\section{VARIOUS CONSTRUCTION METHODS FOR PEAT}

Excavation - displacement and replacement: For case of shallow peat deposit, one solution is to replace the poor soil by excavation or by dumping suitable imported fill materials if the soils are of very high liquid type as illustrated in Fig. 4. This is naturally very expensive on materials. Also it is difficult to control the underground movement of the material. In addition there must be an environmentally acceptable location to waste the excavated soil within an economically acceptable haul distance and there must be a source of adequate fill again within an economically acceptable haul distance ${ }^{[3]}$. Besides this method can only be effective for up to a depth of $5 \mathrm{~m}-6 \mathrm{~m}$. 


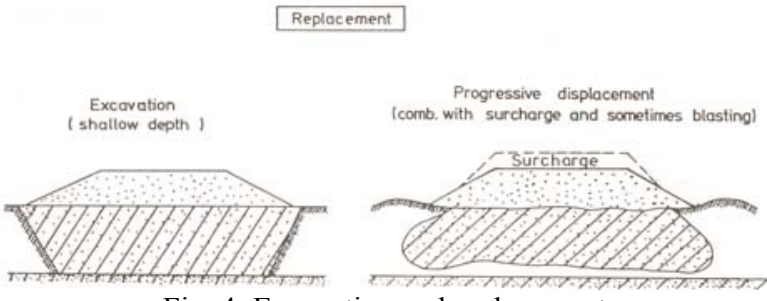

Fig. 4: Excavation and replacement

Deep stabilization method: For case of deep peat, deep stabilization technique might be employed. This technique is quite popularly used for stabilization of soft soil in Sweden and Finland ${ }^{[4]}$. Unslaked lime has been replaced with cement/lime mixes usually in the ratio of 50:50, while pure cement has also been in application. Strengths of silt and clay can be improved up to 30 fold. In peat however the strength gains may not be that high. High water content and low strength of peat require significant strength gain, which is inhibited by organic matter (Fig. 5).

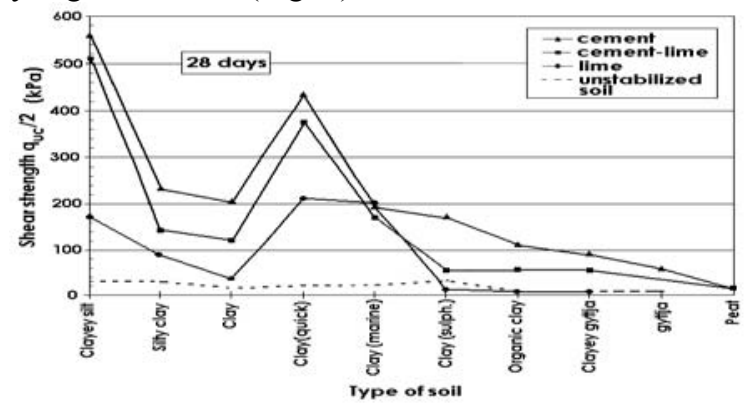

Fig. 5: Shear strength gain (28 days) of various types of soil $^{[4]}$.

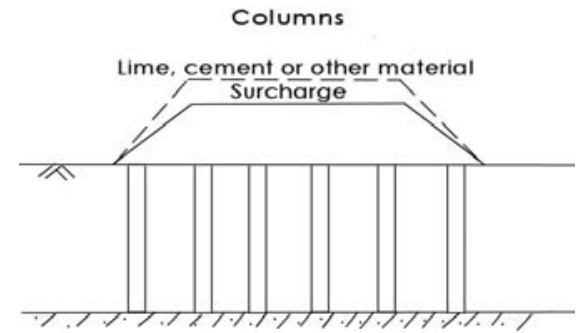

Fig. 6: Lime/cement columns

However, by adding enough stabilizers such as cement, the strength gain may be adequate. Pure cement is found to be more effective in peat than cement/lime mixtures and certain additives such as gypsum, improve the cement reactivity. Strength gain is mainly due to hydration products formed by cementitious reactions. Strength gain depends on type of soil, dosage of binder, water content, and curing conditions. Mechanisms of organic matter interference in strength gain is not completely understood but is thought to include the following ${ }^{[5]}$ :
- Organic matter can alter composition and structure of calcium silica hydrate (C-S-H) gel, a cementing compound that forms bonds between particles and also type and amount of other hydration products, e.g., ettringite.

- Organic matter holds 10 or more times its dry weight in water and may limit water available for hydration.

- Organic matter forms complexes with aluminosilicates and metal ions interfering with hydration.

Fig. 6 illustrates the application of lime/cement columns as deep stabilizers. Huttunen et al. ${ }^{[6]}$ reported the unconfined compressive strength of peat with different degree of humification. They found that strength increases with the increase in dosage of cement and decreases as humification increases, and the chemical and physical properties of the peat (water content, organic content) dictate the reaction with the binding agent.

Deep Soil Mixing (DSM), also referred to, as the Lime/Cement Column Method, or just Cement Columns is a variant of the deep stabilization technique, invented by Kjeld Paus almost 30 years ago. It is a form of soil improvement involving the introduction and mechanical mixing of in-situ soft and weak soils with a cementitious compound such as lime, cement or a combination of both in different proportions.

The binder is injected into the soil in a dry form. The moisture in the soil is utilized for the binding process, resulting in an improved soil with higher shear strength and lower compressibility. The removal of the moisture from the soil also results in an improvement in the soft soil surrounding the mixed soil. Dry DSM methods have been used in Sweden and Finland since 1967 for soil improvement in soft clays and organic soils and are mainly used to increase the stability and to reduce the settlements of embankments. A typical dry DSM unit consists of a track mounted installation rig fitted with a leader and a drill motor as shown in Fig. 7. The binder is carried in pressurized tanks, which are mounted on the rig itself or on a separate shuttle.

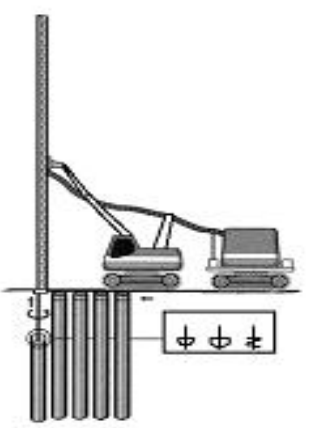

a)

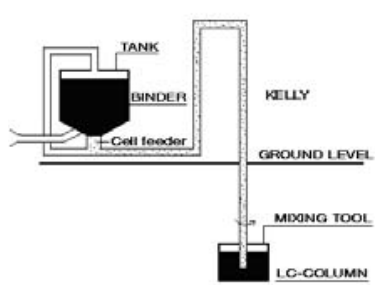

(b)
Fig. 7: (a). Schematic showing a Dry DSM machine installing columns (b) Photo showing the ejection of the binder from the mixing tool in a dry form (Source: LCM Marktechnik) 
A research has been carried out in University Putra Malaysia (UPM) to examine the effect of cement column on the compressibility of peat soil ${ }^{[7]}$. When a cement column is installed in peat, its compressibility is reduced because of the hardened skeleton matrix formed by cement particles bonding with adjacent soil particles in the presence of pore water. The effects of the cement column diameter on the compressibility have been investigated in this study. The results indicated that compressibility index $C c$ and $C \alpha$ decreased with increasing diameter of the cement column. Specimens with $45 \mathrm{~mm}$ and $60 \mathrm{~mm}$ diameter of cement columns were cured for 28 days, after which they were subjected to Rowe Cell Consolidation test ${ }^{[7]}$. Undisturbed samples of peat soil were taken from three different locations in Banting (located on the West coast of Peninsular Malaysia) by using a sampling tube. A suitable auger was designed and fabricated to collect undisturbed peat samples. The auger enables the extraction of peat core sample of $150 \mathrm{~mm}$ diameter by $230 \mathrm{~mm}$ length. Fibrous soil such as peat is easily disturbed therefore the trimming process was carried out carefully. Furthermore, the trimming process was carried out quickly to minimize the change in the water content of the soil sample.

Sample was then tested using Rowe Cell to overcome most of the disadvantages of the conventional oedometer. The most important features are the ability to control drainage and to measure pore water pressure5. during the course of consolidation tests. Fig. 8 shows the experimental set up of using Rowe Cell. The hydraulic loading system pressure to be applied and vertical load can be applied to the sample surface either via a flexible diaphragm to give a uniformly distributed pressure (free strain) or via a rigid plate to give uniform settlement (equal strain).

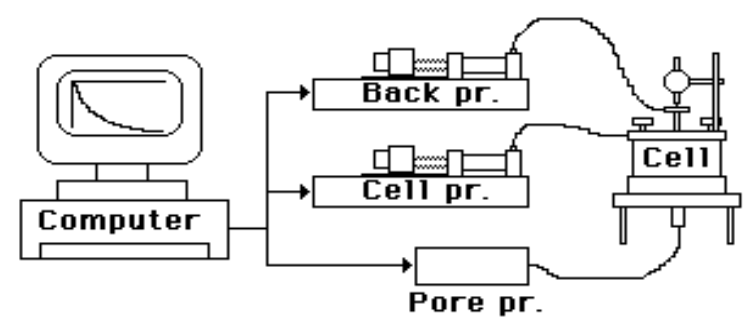

Fig. 8: Consolidation test using Rowe Cell

The following are the main conclusions drawn from the consolidation test described above:

1. Based on the compression ratio, untreated (natural) fibric peat sample was very compressible whereas hemic peat sample was moderately compressible prior to stabilization. Fibric peat sample recorded compression ratio of $0.20-0.35$ while hemic peat sample recorded values of $0.10-0.20$. Hence, it suggests that fibric peat is more compressible than hemic peat. After the cement column stabilization, the compression ratio of both samples decreased considerably.

2. Compression index of fibric peat sample was reduced by $60 \%$ using cement column of 45 $\mathrm{mm}$ diameter and $80 \%$ with cement column of $60 \mathrm{~mm}$ diameter. In the case of hemic peat sample, it was $50 \%$ reduction with $45 \mathrm{~mm}$ diameter cement column and $90 \%$ with $60 \mathrm{~mm}$ diameter cement column. Hence, it suggests that larger diameter cement column has a higher reduction effect in the compression index.

3. Coefficient of volume compressibility was reduced by approximately $50 \%$ with cement column. The reduction is more pronounce with larger cement column.

4. Cement column successfully reduced the $C \alpha$ $/ C c$ values in the range of $0.03-0.05$. It is significantly smaller than natural (untreated) peat due to very small secondary consolidation.

Compressibility parameters which are compression index and secondary compression are significantly improved with cement column.

Preloading and vertical drains: Preloading principle was adopted with idea to minimize post construction settlement. The basis of preloading is to place a temporary fill over the construction site that is thicker than the final design fill. This causes settlement to occur more rapidly than would have occurred under the final fill design height. The preload is ideally left in place until it has settled more than the total amount that the design fill is expected to settles in its design life.

Preloading principle, often incorporated with vertical drains, was also adopted in the abovementioned methods to accelerate settlements and minimize post construction settlement (see Fig. 9). Where it is desirable to try to speed up dissipation of pore water pressures beneath an embankment and hence speed up the settlement process, then geosynthetic vertical drains have become a modern substitute for the sand drains. They are two basic reasons to wish for the quick dissipation of the pore water pressures: in a stage construction, where strength gain of the subsoil at each 
stage is needed to ensure the stability of the next stage, then quicker dissipation allows quicker construction; in preloading to reduce the time necessary for the preload fill to remain in place. Geosynthetic vertical drains are commonly $100 \mathrm{~mm}$ wide and $5 \mathrm{~mm}$ thick and are composed of a plastic drainage core wrapped in nonwoven geotextile sock. They come in long rolls and are commonly punched into the ground with a mandrel in a triangular or square configuration with spacing of $1 \mathrm{~m}$ to $2 \mathrm{~m}$ to whatever depth is required.

With this punching process comes a problem for this technology, namely the displacement and disturbances of the soil by the mandrel and the smearing of the geotextile sock by the disturbed soil. This can cause a radical decrease in permeability at the drain entrance, and prevent free drainage expected. There had been considerable discussions concerning this topic and whether the drains do in fact works. An example is presented by Othman et al. ${ }^{[8]}$. Specifically for peat, the high initial permeability of the peat may render the drains useless. Later in the consolidation process, permeability might decrease to levels making the drains effective, but buckling and filter contamination might render them less effective before then $^{[9]}$.
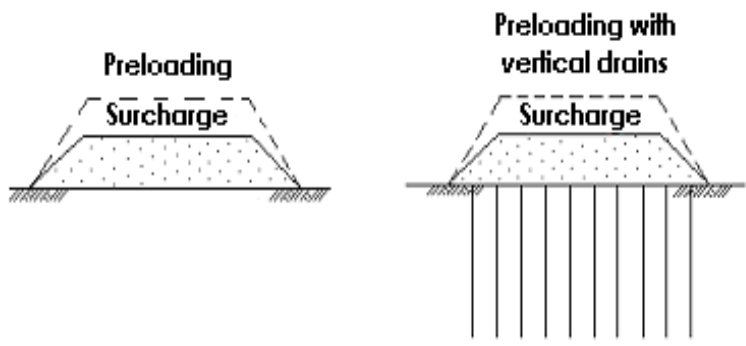

Fig. 9: Preloading (stage construction) and vertical drain

Lightweight foundation system: Lauritzsen and Lee [10] described a feasibility study carried our by the Norwegian Geotechnical Institute (NGI) for UTRACO Construction Sdn. Bhd, to assess the suitability of using lightweight Expanded Polystyrene, EPS as foundation material in a housing scheme. A pure technical desk study was performed to investigate the possibility to build directly on the marshland by means of EPS (Expanded Polystyrene). Direct foundation of houses, roads and gardens on swampy, peaty, soft soil conditions was considered using the regular principles of EPS foundation.

Below is the summary of settlements after using EPS in the following structures ${ }^{[10]}$.
Table 1: Summary of settlement calculations

\begin{tabular}{lcccc}
\hline $\begin{array}{l}\text { Structure } \\
\text { Type }\end{array}$ & $\begin{array}{c}\text { After } \\
\text { Construction }\end{array}$ & $\begin{array}{c}\text { Settlements }(\mathrm{cm}) \\
\text { After } \\
\text { Consolidation }\end{array}$ & $\begin{array}{c}\text { After } \\
20 \\
\text { years }\end{array}$ & $\begin{array}{c}\text { After } \\
50 \\
\text { years }\end{array}$ \\
\hline House & 28 & 62 & 71 & 80 \\
$\begin{array}{l}\text { Standard } \\
\text { Road }\end{array}$ & 33.5 & 78.5 & 86.5 & 95.5 \\
$\begin{array}{l}\text { Concrete } \\
\text { Road }\end{array}$ & 30 & 44 & 54 & 62 \\
Garden & 28 & 41 & 51 & 59 \\
\hline
\end{tabular}

The most important principle in this study was to avoid uplift during flood and to keep the loads at minimum. Using the best geotechnical soil properties estimations and based on the investigations, observations and experience, it was found to be feasible solution $^{[10]}$. However, before any construction takes place in the field, it is strongly recommended to verify the many assumptions made, by loading test in the field, soil investigations and laboratory testing.

\section{CONCLUSION}

The choice of method of improving peat ground for utilization in housing scheme is a matter of finding optimal solutions between economic and technical factors, available construction time, and the target performance standards. Undoubtedly construction in peat soil is not easy but with better understanding, it can be more manageable. Evaluating the effectiveness of the various methods introduced in this paper need to be considered.

\section{REFERENCES}

1. Huat, B.B.K. 2004. Organic and Peat Soil Engineering. University Putra Malaysia Press.

2. Tai, L. Y. and K.W. Lee. 2003. Some interesting aspects of peat formations in Sibu Town and related engineering issues. Proceedings of $2^{\text {nd }}$ International Conference on Advances in Soft Soil Engineering and Technology. (eds). Huat et al. Putrajaya, Malaysia. pp. $725-740$.

3. Jarrett, P.M. 1995. Geoguide 6. Site Investigation for Organic Soils and Peat. JKR Document 207090341-95. Institut Kerja Raya Malaysia.

4. Ahnberg, H., C. Ljungkratnz and L. Holmqvist. 1995. Deep stabilization of different types of soft soils. Proceedings 11 ECSMFE, Copenhagen, Vol. 7, pp. 167-172.

5. Janz, M. and S.E. Johansson. 2002. The function of different binding agents in deep stabilization. Swedish Deep Stabilization Research Center, SGI, Report No. 9, Linkoping. 
6. Huttunen, E., K. Kujala, and H. Vesa. 1996. Assessment of the quality of stabilized peat and clay. Symposium Grouting and Deep Mixing. Leiden: Balkema. 607-612.

7. Duraisamy, Y., B.B.K. Huat, R. Muniandy, R. and A. Aziz. 2006. Compressibility Behavior of Tropical Peat Soil. $2^{\text {nd }}$ International Conference on Problematic Soils. C18 IEAG. Petaling Jaya. 3-5 ${ }^{\text {th }}$ December 2006. 187-196.

8. Othman, K.H., B.B.K. Huat, C. Chin and F.H. Ali. 1994. Observed performance of some vertical drain embankments in Malaysia. Conference on Geotechnical Engineering. Geotropika 94. Malacca.
9. Den Haan E. J. 1997. An overview of the mechanical behaviour of peats and organic soils and some appropriate construction techniques. In the Proceedings of Conference on Recent Advances in Soft Soil Engineering, Kuching. Sarawak. Huat, B.B.K, \& H.M. Bahia (eds). 17-45

10. Lauritzsen, R. and L.T. Lee. 2002. EPS foundation for marshland Sarawak. In proceedings of $2^{\text {nd }}$ World Engineering Congress. (Ed) Huat et al., Kuching. Sarawak, pp. 203-207. 